University of Wollongong

Research Online

Faculty of Business - Papers (Archive)

Faculty of Business and Law

2013

\title{
A Praxis framework for implementing market orientation into charities
}

Paul Chad

University of Wollongong, pchad@uow.edu.au

Judith Motion

University of Wollongong, jmotion@uow.edu.au

Elias Kyriazis

University of Wollongong, kelias@uow.edu.au

Follow this and additional works at: https://ro.uow.edu.au/buspapers

Part of the Business Commons

Research Online is the open access institutional repository for the University of Wollongong. For further information contact the UOW Library: research-pubs@uow.edu.au 


\title{
A Praxis framework for implementing market orientation into charities
}

\begin{abstract}
There is a scarcity of research regarding the process of introducing market orientation into the not-forprofit sector. Understanding this process would greatly assist the not-for-profit sector, which is under increasing pressure to obtain funds to operate and offer appropriate services. In this article, we examine the successful introduction of market orientation into three Australian charities and identify the stages of implementation. The introduction of market orientation is analyzed from a discourse transformation perspective and a praxis framework is developed. This is amongst the first studies examining the transition to a market orientation discourse within charity organizations and the first study to develop a praxis framework to guide managers. The study also pioneers a discourse transformation perspective in market orientation research. The article thus extends our knowledge of market orientation within the notfor-profit sector and increases understanding of practitioner engagement in marketing activities.
\end{abstract}

\section{Keywords}

charities, orientation, market, implementing, framework, praxis, into

Disciplines

Business

\section{Publication Details}

Chad, P., Motion, J. \& Kyriazis, E. (2013). A Praxis framework for implementing market orientation into charities. Journal of Nonprofit and Public Sector Marketing, 25 (1), 28-55. 


\title{
A Praxis Framework For Implementing Market Orientation Into Charities.
}

\author{
Dr Paul Chad \\ Dr Judy Motion \\ Dr Elias Kyriazis
}

\begin{abstract}
There is a scarcity of research regarding the process of introducing market orientation into the not-for-profit sector. Understanding this process would greatly assist the not-for-profit sector, which is under increasing pressure to obtain funds to operate and offer appropriate services. In this paper, we examine the successful introduction of market orientation into three Australian charities and identify the stages of implementation. The introduction of market orientation is analysed from a discourse transformation perspective and a praxis framework is developed. This is amongst the first studies examining the transition to a market orientation discourse within charity organisations and the first study to develop a praxis framework to guide managers. The study also pioneers a discourse transformation perspective in market orientation research. The paper thus extends our knowledge of market orientation within the not-for-profit sector and increases understanding of practitioner engagement in marketing activities.
\end{abstract}

Keywords: market orientation, charities, non-profit, not-for-profit, case study, discourse

Running head: Implementing Market Orientation Into Charities 


\section{INTRODUCTION}

Charity organisations play a significant role in improving the welfare of societies and their economies. Traditionally, charities have appealed to the social conscience of communities to fund services. However, increased competition amongst numerous charities has created pressure to improve fundraising and service delivery performance. The challenge for charity organisations is to change their practice without compromising their ethos. Adoption of effective business practices is essential but may clash with the philosophy and culture of charity organisations and potentially alienate significant stakeholders. The aim of this paper is to develop a managerial praxis framework for the successful introduction of a market orientation (MO) into charity organisations. A discourse analytic approach is used to examine how three charity case study organisations move to a more market oriented mode of operation. The discourse analytic approach is based on Michael Foucault's (1991) work on discourse transformation and concentrates on how shifts in meaning modify the way organisational stakeholders perceive systemic change. Two key research questions are addressed: first, what are the processes for effectively introducing market oriented discourses in a charity organisation? Second, what is an appropriate praxis framework for successfully introducing MO into charity organisations?

MO has received widespread attention in the marketing literature over the past two decades and the adoption of MO has been shown to be associated with improved performance within organisations (Jaworski \& Kohli, 1993). The research has typically been conducted in a for-profit setting. The actual process of implementing MO has received little attention in either the for-profit or the not-for-profit sector. Harris (2000) examined the barriers to developing a MO and concluded that 'comparatively few studies have examined the processes and dynamics of developing market orientation' (p. 619). Similarly, Beverland and Lindgreen (2007) contend 
that 'only one study has examined the implementation of a market orientation' (p. 430) and that examining the change process would substantially increase our knowledge by determining practical implications. This issue was subsequently addressed by Beverland and Lindgreen (2007) within the context of two agricultural organisations. However, to date, no such research has been conducted in the not-for-profit sector.

This paper addresses the aforementioned gap in the existing literature and examines the manner in which managers conduct the process of change within charities, a specific sub-sector of the not-for-profit sector, and hence responds to calls from Harris (2000), Kennedy, Goolsby and Arnould (2003) and Beverland and Lindgreen (2007) to progress research into the manner in which MO is actually introduced into organisations. This paper also assists in addressing the comment by Tadajewski and Hewer (2011) 'that there needs to be a concerted effort in understanding how practitioners engage in marketing activities' (p. 451). This issue is significant because charities play a key role in society and increased competition has resulted in numerous charities struggling to survive. Improving the performance of charities will assist them to better satisfy the needs of society.

The research contributes in a number of ways. Amongst the first research to examine how MO can be successfully introduced into charities, the resultant praxis framework is a significant contribution to the literature and will guide and direct managers within the charity sector to improve performance. In doing so, it has 'the potential to enrich marketing practices' (Tadajewski \& Hewer, 2011, p. 449) and ‘transform the intellectual and practical landscape’ (p. 452). Likewise, the research contains elements of 'novelty and continuity' (p. 450) by continuing the examination of the MO concept from a discourse transformation perspective. 
Within the paper, we review relevant aspects of MO and justify the relevance of MO for the not-for-profit sector. The research approach is outlined and the findings of the three case studies are presented enabling our subsequent development of a praxis framework for implementation of market orientation within charities. Finally, we provide a discussion and identify our key contributions, followed by a conclusion.

\section{THE MARKETING CONCEPT AND MARKET ORIENTATION}

The marketing concept is defined by Kotler and Armstrong (2012) as the management 'philosophy that holds that achieving organisational goals depends upon knowing the needs and wants of target markets and delivering the desired satisfactions better than competitors' (p. 34). Formulation of the marketing concept originated 'in the 1950s in the context of business firms'

(Mukkerji 2004, p. 9). The marketing concept has long been viewed as the main way for organisations to create satisfied customers and considered the primary objective of organisations (Drucker, 1954; Levitt, 1960). Kohli and Jaworski (1990) regard the marketing concept as a business philosophy and 'a market-oriented organisation is one whose actions are consistent with the marketing concept' (Kohli \& Jaworski, 1990, p. 1). Significant research evidence suggests that a high level of MO is associated with a high level of business performance in commercial for-profit organisations. Emphasising this, a meta-analysis conducted by Shoham, Rose and Kropp (2005) covering fifteen years of published research concluded that MO has a significant impact (directly, indirectly and totally) on performance.

Early MO research was led by Narver and Slater (1990) and also Kohli and Jaworski (1990). Narver and Slater (1990) developed the 'Independent Effects Model' of relationships between MO, business-specific factors, market-level factors and business performance and 
suggested that MO 'is a one dimension construct consisting of three behavioural components and two decision criteria - customer orientation, competitor orientation, interfunctional coordination, a long-term focus, and a profit objective' (Narver \& Slater, 1990, pp. 21-22). In parallel to the Narver and Slater (1990) research, Kohli and Jaworski (1990) considered MO to revolve around market intelligence (intelligence generation, intelligence dissemination and responsiveness) and shortly afterwards proposed a model suggesting the nature of top management, interdepartmental dynamics and organisational systems influenced MO, and that MO consequently influenced employees and business performance (Jaworski \& Kohli, 1993).

Lafferty and Hult (2001) later conducted a meta-analysis of published MO research. In comparing the decision-making perspective (Shapiro, 1988), market intelligence perspective (Kohli \& Jaworski, 1990), culturally based behavioural perspective (Narver \& Slater, 1990), strategic approach (Ruekert, 1992) and customer orientation perspective (Deshpande, Farley, \& Webster Jr, 1993), they suggested four key ‘synthesis dimensions’ of MO, namely: emphasis on customer, importance of information, interfunctional coordination and taking action. These principles were developed in the context of for-profit organisations, with no consideration given to their relevance within not-for-profit organisations.

\section{MARKET ORIENTATION AND NOT-FOR-PROFIT ORGANISATIONS}

MO 'in the for-profit sector is one of the most researched fields in the marketing discipline. However, not-for-profit marketing as a whole and MO of not-for-profit organisations in particular are largely under-researched areas’ (Modi \& Mishra, 2010, p. 565). Despite being a neglected research area in regards to MO, marketing is relevant to not-for-profit organisations

(Drucker, 1990; Kotler \& Andreasen, 1996) and given the key role that such organisations play 
in society (Pope, Isely, \& Asamoa-Tutu, 2009), should be the focus of further research. This would assist managers of not-for-profit organisations who lack an appreciation of 'the meaning, importance, and relevance of the marketing concept to NPOs’ (Modi \& Mishra, 2010, p. 549). Not-for-profit organisations play a key role not just within society, but also within the overall economy and contribute ten percent of GDP in the USA (Daystar Council, 2011), over four percent in Australia (Productivity Commission, 2010) and around four percent in the UK (Charity Commission, 2011).

The key differences between for-profit and not-for-profit organisations are the economic rationale based on profit and loss considerations of for-profit organisations, whereas a not-forprofit organisation is socially oriented and based on helping people who have a generally less than optimal life situation. Sargeant, Liao and Foreman (Liao et al., 2001; Sargeant et al., 2002) modified the original MO models developed for large for-profit organisations (Narver \& Slater, 1990; Kohli \& Jaworski, 1990) and proposed a societal orientation model for the not-for-profit sector. They renamed 'customer' as 'stakeholder' and an additional component named 'collaboration' was included to accommodate situations whereby some competitors in the notfor-profit sector sometimes work together to provide synergy in service delivery. Gonzalez, Vijande and Casielles (2002) also modified the MO model of Kohli and Jaworski (1990) and divided customers into donors and beneficiaries. More recently, Duque-Zuluaga and Schneider (2008) divided the 'customer' in the MO model of Narver and Slater (1990) into beneficiary/recipient, donor, volunteer/employee and added a new component referred to as 'collaborative orientation'. Duque-Zuluaga and Schneider (2008) also added learning and entrepreneurship to their model, but this is often regarded as a moderator/antecedent to MO by other researchers. 


\section{IMPLEMENTING MARKET ORIENTATION}

Various models have been developed regarding the linkages between aspects of organisations and MO but these do not actually explain how to implement MO. Indeed, Beverland and Lindgreen (2007) contend that the literature 'is silent on the process involved in moving firms to a market orientation' (p. 430). Taghian (2010) regards implementation of MO as underresearched and considers that what research does exist typically examines the antecedents to achieving MO rather than the actual implementation. In 2007, Beverland and Lindgreen stated that Kennedy et al. (2003) had conducted the only empirical examination of implementing a MO - this involved comparison of attempts by two schools to introduce MO and identified leadership support and interfunctional coordination as key issues. Beverland and Lindgreen (2007) subsequently examined the introduction of MO into two agricultural firms in New Zealand.

Using an ethnographic study of seven firms, Gebhardt, Carpenter and Sherry Jr (2006) suggested a four-stage model for the process of introducing MO: namely, initiation, reconstitution, institutionalisation and maintenance. Whilst research into the actual implementation of MO is under-researched, there has been various research regarding 'barriers' to use of MO (e.g. Harris, 1998). Wong, Saunders and Doyle (1989) considered a key barrier to introduction of a MO is the difficulty in attempting to change traditional thinking, the selfinterest of staff and lack of cooperation between functional units. Harris and Ogbonna (2001) have identified leadership style as a key to successful introduction of MO. Other reasons offered for non-achievement of $\mathrm{MO}$ include flawed measures of customer satisfaction, inappropriate customer complaint mechanisms, rejection of competitor threats and strategic inertia (Mason \& Harris, 2005). Barriers are both system-focused (Harris \& Piercy, 1999) as well as people- 
focused/cultural (Gainer \& Padanyi, 2005). In terms of antecedents of MO, based on a review of MO literature, van Raaij and Stoelhorst (2008) suggested seven 'enablers’ of MO - structure, process design, information systems, reward systems, leadership, behavioural norms and values, competence management. All of the research outlined in this paper regarding barriers and antecedents to the introduction of MO has been conducted within a for-profit context except the research of Gainer and Padanyi (2005).

In summary, various researchers have developed models of MO for both the for-profit and notfor-profit sectors. However, the process of how MO is actually introduced into organisations is under-researched; most of the research identified barriers to the introduction of MO rather than determining the actual process of how it can be successfully introduced. Therefore we focus on two research questions: first, what are the processes for effectively introducing market oriented discourses in a charity organisation? Second, what is an appropriate praxis framework for successfully introducing MO into charity organisations?

\section{RESEARCH APPROACH}

This research concentrates on charities because of the wide range within the not-for-profit subsectors, for example charities, cultural groups, hospitals, libraries, universities and political parties which may operate in different ways and thus not be appropriate to examine in one research project. The model and definition of MO used for the research is based upon Lafferty and Hult's (2001) meta-analysis because it provides a synthesis of the views of various key researchers, particularly the research of Kohli and Jaworski (1990) and also Narver and Slater (1990) upon which the not-for-profit models are based. 
The research in this paper examines how charities change as management introduces MO. To assess this change, a discourse analytical approach is adopted as the epistemic foundation. Ellis, Jack and Higgins, (2005) stated that 'a discursive approach is gaining increased interest in marketing ...' (p. 124). Discourse may be understood as a system of thought or a 'grand narrative' (Ellis et al., 2011, p. 59) that constructs the world in meaning; it influences everyday thought, talk and practice (Foucault, 1991). Institutional domains, such as health, law, education, and commerce, are the most prevalent sources of discourse. Foucault (1991) offered an analytical tool for identifying and examining discourse transformation. First, discourse transformation may be tracked by an analysis of changes in the substance or meanings of a discourse, its 'objects, operations, concepts, theoretical options' (Foucault, 1991, p. 56). Second, changes may also be detected at the level of discursive function/process - the 'displacement of discourse boundaries', 'the new position and role' of the speaking subject, the 'new mode of functioning of language’, and 'circulation' of the discourse (Foucault, 1991, pp. 56-57). Lastly, changes in the discourse priorities may also be analysed by identifying shifts at the level of multiple discourses - the hierarchy, directing principle and functional displacements of a discourse. A change from a traditional charity discourse to a more market oriented discourse will have occurred if employees 'come not only to act differently but also to understand or "know" the world differently' (Motion \& Leitch, 1996, p. 299). To assess the change within charities, Foucault's (1991, pp. 56-57) criteria for identifying discourse transformations are applied in this research.

Case study methodology (Creswell, 2003) was used as it is considered appropriate for indepth and holistic analysis (Feagin, Orum, \& Sjoberg, 1991) and for use during the formative period of research and theory (Eisenhardt, 1989; Yin, 1994), such as the current situation 
regarding examination of how MO can be successfully introduced into charities. Three cases were conducted as 'multiple cases ... have the advantage of allowing the researcher to triangulate data from multiple sources, thus allowing results to be generalised beyond a single case' (Aaker, Kumar, Day, \& Lawley, 2005, p. 161) and richer theory can be developed from multiple case studies relative to a single case (Eisenhardt, 1989). A criteria-based selection process (LeCompte \& Preissle 1993) was utilised to select the cases. The criteria utilised were not-for-profit charities, operating in the 'health advice and assistance' sector, geographically based in South Eastern Australia and having recently experienced an attempt to introduce a market orientation. The level of success in introducing a market orientation was not a consideration and indeed was not known at time of case selection. The focus on a single 'industry' also reduced the likelihood of external influence (McDonald 2007). For confidentiality, the case organisations will be referred to by the pseudonyms Arana, Bukari and Camira.

Semi-structured in-depth interviews utilising open-ended questions were used to explore the 'lived experience’ (Covaleski, Dirsmith, Heian, \& Sajay, 1998) of those being interviewed. An interview protocol (Yin, 1994) was utilised to ensure consistency. Topics for discussion were particularly informed by Lafferty and Hult's (2001) four synthesis dimensions of MO and Foucault's (1991) framework 'for detecting the changes which affect the discursive formations' (p. 56). Guidelines for conducting interviews suggested by Patton (2002, see pp. 343-380) were followed. Interviews were augmented with direct observation, archival material and various artefacts considered appropriate (Gillham, 2000), including annual reports, organisational induction manuals, strategic plans, organisation brochures, newsletters, examples of client surveys and organisational internet sites. The 'triangulation made possible by these multiple data 
collection methods provided substantiation of constructs and hypotheses' (Eisenhardt, 1989, p. 538) and use of multiple sources increased the validity of the research (Haigh, n.d.; Parkhe, 1993).

Within each case, theoretical sampling of interviewees was conducted to build and refine emergent theory (Eisenhardt, 1989; Glaser \& Strauss, 1967; Yin, 1984). In-depth interviews were initially conducted with the Chief Executive Officer (or equivalent). Employees (possessing a variety of backgrounds, experience and training) from all levels of the organisations (vertical) and across all functional areas (horizontal) were interviewed to gain a comprehensive perspective (Steinman, Deshpande, \& Farley, 2000; Webb, Webster, \& Krepapa, 2000). Theoretical sampling stopped upon 'saturation' when 'a sufficient number of arguments of sufficient quality and sufficient data for those arguments to be well grounded' (Wood \& Kroger, 2000, p. 81) were obtained. Fifteen participants were interviewed at Arana, ten at Bukari and fifteen at Camira. A single interviewer conducted all interviews to minimise bias (Lincoln \& Guba, 1985; Strauss \& Corbin, 1998). The interviews were digitally recorded and subsequently professionally transcribed. Copies of interview transcripts were checked by the researchers and provided to respondents to verify accuracy and, where appropriate, follow-up interviews were used to clarify and elaborate on any issues. Manual thematic analysis of the transcripts was conducted to enable greater 'immersion' of the researchers in the data (Wood \& Kroger, 2000). Analysis was informed by guidelines developed by Patton (2002, see pp. 465-468) and Creswell (2003, see pp. 191-195) to identify emergent themes. Analysis was conducted within-cases prior to cross-case (Miles \& Huberman, 1994).

To ensure research quality, internationally recognised quality practices for case study (e.g. Eisenhardt, 1989; Gummesson, 2007; Stake, 1995, see pp. 107-116; Yin, 1993, see pp. 39-40; 
1994 see pp. 32-38) and qualitative research (e.g. Creswell, 2003, see pp. 195-197; Lincoln \& Guba, 1985; Miles \& Huberman, 1994, see pp. 277-280; Patton, 2002, see pp. 552-584) were utilised.

\section{Background to the three cases}

Arana : Established in 1974, Arana operates within south-eastern Australia and provides a range of services and support for people with a specific medical condition and for their families. Arana is primarily funded by both State and Federal Government. Guided by a somewhat visionary long-term CEO, Arana has progressively introduced MO in a relatively low-key manner since the mid 2000's and has since grown markedly. The period 2007/08 was characterised by significant growth, bedding down new structures and adjusting to life as a much more complex organisation and simultaneously dealing with significant staffing issues (Arana, 2008). Arana currently has 1,700 service recipient clients, 160 permanent staff and 200 casual staff. A newly formed for-profit division not only provides employment for service recipient clients with the specific medical condition, but also competes in the open market to provide various services such as lawn mowing and property maintenance for external, paying clients. Revenue from this fee-for-service division provides additional funds for use within the organisation. The increased revenue has coincided with significant changes towards a more professional and businesslike perspective involving numerous aspects of a market oriented discourse being introduced within the organisation. These changes have included a strong social entrepreneurial focus (including the creation of the for-profit division) as well as increased use of key performance indicators and reporting processes as well as recognition of the need to develop relationship marketing activities with key government fund providers to cement funding sources for the future. 
Bukari : Originating in 1952 as a charity run by parents and interested persons, Bukari began employing professionals in 1968 and is now a national Australian charity employing over 100 staff and forty volunteers (Bukari, n.d.-a). Bukari's aim is to provide education and support services throughout Australia to children and adults with a specific medical condition, raise awareness within the community of the medical condition as well as advocacy/lobbying to government. The national office in Sydney plus regional offices enables Australia-wide coverage.

Services include individual service programs (aimed at individuals and their families), community and professional programs (for schools, police, nurses and other community groups), as well as information and referral services (Bukari, n.d.-b). Bukari mainly relies upon selfgenerated funds (donations, lotteries and bequests). An outbound call centre is operated to contact potential donor clients and lottery ticket purchasers. Operating at a loss, in 2005 the CEO resigned and several members of the senior management team also left. Since then, under the direction of a new CEO, significant changes towards a business oriented perspective involving numerous aspects of a market oriented discourse have occurred within Bukari. These changes were deemed as urgently needed due to the poor financial situation of Bukari. The financial situation was a key influencer in the manner in which the new CEO introduced the discourse transformation.

The new CEO, with the assistance of a new senior management team made changes towards development of a corporate structure to provide a base for service growth (Bukari, 2006) and initiated a strategic planning process including a new vision, new framework and business plan. A three year aim was established to identify client needs, develop quality products, meet or 
exceed the changing expectations of service recipient clients, build organisation capability, introduce new policies and procedures, diversify income streams and raise awareness (Bukari, 2006). Development of a strong direct marketing capability (Bukari, 2007) enabled subsequent growth in revenue, particularly from lottery sales (Bukari, 2009). The current strategy incorporates design of innovative services and delivery tools and commitment to quality services (Bukari, 2008). The success of Bukari's new marketing strategy has enabled a $40 \%$ increase in revenue over the period 2005-2010. The new market orientation of Bukari is emphasised in its new mission statement based upon delivery of innovative, high quality education and support services as well as listening, responding, continually improving and innovating (Bukari, n.d.-c).

Camira : Operating as the community care division of the Sydney (Australia) operations of a Christian-based church, Camira was formed 150 years ago and currently provides care of the aged and disadvantaged, and the love of Christ expressed in practical ways within the community (Camira, 2007). Regional offices are located throughout the greater-Sydney area, with 1,400 paid staff and 2,000 volunteers providing the range of services. Battling financially and operationally, a major re-structure occurred within Camira in 2006. The then CEO (with a theological background) retired and all six general managers also left the organisation. A new CEO with business experience was recruited with the express mandate to re-invigorate the organisation. This was the first time that Camira has ever had a CEO from a non-theological background.

A strategic plan was developed which assumes a dynamic and changeable future. The plan was based on an extensive environmental analysis that included engagement via interviews of a broad range of stakeholders (Camira, 2007). Thus, introduction of a new CEO possessing a 
strong business background signalled the commencement of a new era for Camira, with a more market oriented discourse being introduced. Government funding accounts for 57\% of Camira's total income and steps have recently commenced to reduce reliance on government funding via development of corporate donation income streams. Despite the introduction of a more businesslike perspective, Camira still maintains a strong religious base and aims for all senior management and other key positions to be filled by Christians from Bible-based churches.

\section{FINDINGS}

\section{Traditional Charities}

A traditional charity discourse was characterised by notions of people needing help, being objects of pity, tragic, low achievers, dependent on others, and victims of circumstance (Fulcher, 1989). Respondents perceived traditional charity organisations as typically entailing small-scale activity, a reliance on volunteers, and operating in an inefficient and unsophisticated manner. Traditional charities were regarded as being reactive and having a welfare-based orientation, fund-raising was low-scale and unsophisticated. Corporations were not targeted for funds and traditional charities were perceived as having little or no professional fund-raising employees. The three charities examined in this paper were traditional charities that have recently had MO introduced.

\section{Implementing market orientation: A three stage process}

We have identified that MO was implemented within the charities in three transitional phases: a new managerialism phase, a professionalism phase and a subsequent embedding phase. Within Arana, the progressive CEO with managerial skills anticipated the need for change, whereas the 
catalyst for change within both Bukari and Camira was poor financial performance. The long held assumptions that the organisations would survive in the newly competitive environment whilst still operating as traditional charities were challenged. Senior management with appropriate business skills were introduced into Bukari and Camira. Thus, new managerialism was the first phase needed within these charities to become more market oriented.

New managerialism has a 'concern for efficiency, cost-effectiveness and competition' (Gewirtz \& Ball, 2000, p. 256). Emergence of new managerialism is associated with 'new icons such as outcomes and missions, and new rituals to enshrine them including corporate planning, performance evaluation and new fiscal accountability arrangements' (Sinclair, 1996, p. 234). Incorporation of management techniques from for-profit businesses (Meyer, 2002; Vickers \& Kouzmin, 2001) resulted in the transformation of charities into businesses.

The second phase towards MO for charities that we identified was the introduction of 'professionalism'. This was a major discursive shift from the traditional charity discourse characterised by volunteers. To provide the charities with the human capital necessary to deliver MO, volunteers were replaced by paid professionals, paid non-professionals were trained to become more professional, and even professionals with non-business backgrounds were required to gain professional business skills. This was most evident within Arana (who utilised consultants to provide training) and Camira (who offered University based courses to existing employees). Bukari, due to very tight financial constraints used in-house training offered by the CEO. Charities must 'be good at learning' and able to improve employee capabilities (Bennett, 1998a, p. 12). Employees were required to be more accountable and skilled at service delivery. Following the foundations built via new managerialism and professionalism, the charities were 
then in a position to utilise the new resources to subsequently consolidate and embed new practices consistent with market oriented behaviour.

Application of Foucault's (1991) criteria for detecting discourse transformation identified that each charity had successfully moved from a traditional charity mode of operation to a more market oriented discourse and practice. The challenge was to map how the inclusion of a market oriented discourse was implemented and impacted on the charities. The fundamental systems of meaning that shape charities were examined. The discourse boundaries (Foucault, 1991) that control what is included in how we think about charities were expanded to include economic practices, the charities had all introduced dimensions of social entrepreneurialism practices and Bukari had also introduced state-of-the-art direct marketing activities. Although the discourse boundaries relating to operating functions had changed, an underlying charity ethos of client-first was maintained. Employees gained a 'new position and role' (Foucault, 1991, p. 56) within the change to a market oriented discourse and were required to possess a higher level of skills and operate in a more professional manner. Fournier (1999) suggests that professionalism can be used to embed what management considers to be appropriate work identities, conduct and practice. This was a significant change affecting employees across all three cases and supports Evetts (2003) who observed that 'the discourse of professionalism is increasingly used' (p. 23) in organisations and can be used by management 'as a mechanism of occupational change and control' (p. 32). The move from the traditional charity discourse that was characterised by volunteers to a more businesslike discourse required increased professionalism. One service provider commented that the 'differences would have to be professionalism ... our accountability on record keeping, documentation. Just the whole thing'. The changes did cause some issues but were accepted overall as indicated by a service provider - 
Some people 'had a real culture shock, there were a few resignations [but also] the ones that are still here are just so impressed with what has happened and the changes that have happened ... those people who are still here are really appreciative of the fact that we can see the [service recipient] clients are benefiting from what's happened'.

There was what Foucault (1991, p. 57) referred to as a 'new mode of functioning of language' within each charity as MO was introduced. The language of business was introduced by the new managers with phrases such as service delivery, strategic planning and best practice being introduced. A service provider commented -

'It was a very challenging time, I am the last remaining manager from the original group. At the point when we got a new CEO, they came from a services marketing perspective, I come from an acute care nursing perspective, I had never been exposed to that before, so it is a completely new concept and the language, it was like a foreign language'.

Managers utilised various methods to introduce and embed the new modes of discourse and operation. Arana, utilised sub-committees, Bukari used direct management/employee meetings (due to the relatively small size and centralised location of employees), whilst Camira gained employee buy-in by inviting all employees to an initial strategic planning day then using various ongoing employee committees. The new CEO of Bukari commented -

'the biggest thing facing me has actually been trying to bring some cultural change about in the organisation. Because I could see the need to do things but I couldn't get the, you know, it has been a struggle to get the troops to see where we needed to go'.

Similarly, communication was regarded as a key to introducing the change with a senior manager commenting - 
'I think the key is communicating the changes to staff before they are implemented, and if you communicate to people the change and you explain to them why you are doing [it] and what the benefit to the organisation is going to be [they will accept the need for change]'.

Utilising Lafferty and Hult's (2001) four synthesis dimensions of MO, Appendix 1 indicates the change in levels of $\mathrm{MO}$ within the charities based on the managerial interventions. 'Emphasis on customer' is a trait of traditional charities and this was maintained in the new discourse. The other three dimensions of MO increased in the new discourse indicating that management had been successful in introducing MO. Appendix 1 contains quotations in italics obtained from employees that justify the identification of new levels of MO. Traditional charities operate in a relatively unsophisticated manner with few records of donors or service recipients. The more market oriented mode of operation resulted in the organisations introducing information gathering procedures and recognising the benefits of data regarding donors hence greater appreciation of the 'importance of information'. The increased professionalism and skilling assisted improved 'interfunctional coordination'. Introduction of service delivery processes based around standard procedures assisted improved 'taking action'.

\section{A praxis framework for implementing market orientation within charities}

Insights gleaned from the interviews have identified that all three charities have successfully introduced MO, and the phases by which the transformation occurred. This data was drawn upon to develop a conceptual praxis framework for implementing MO into charities that is provided in Table 1. To develop the framework, we firstly identified the relevant characteristics that a charity needs to consider (left hand column of Table 1). This list of characteristics was drawn from 
various market/societal orientation models (Duque-Zuluaga \& Schneider, 2008; Gonzalez et al., 2002; Kohli \& Jaworski, 1990; Kohli, Jaworski, \& Kumar, 1993; Lafferty \& Hult, 2001; Liao et al., 2001; Narver \& Slater, 1990; Sargeant et al., 2002). Following compilation of these characteristics, the data obtained from the three case studies enabled development of management praxis guidelines to assist successful implementation of MO into charities. The content of the Table is now discussed.

\section{INSERT TABLE 1 ABOUT HERE}

\section{Organisation mission (values and beliefs) and strategy}

Client focus is a key aspect of MO. Charities typically have an inherent strong focus on service recipient clients so should maintain this focus after the discourse transformation and, in fact, can utilise the existing service recipient client focus as a bridge and legacy from the previous discourse to gain 'buy-in’ from employees. Thus, maintenance of high client focus should be regarded as the foundation of the new market oriented discourse. As well as continuance of this high focus, the focus on service recipient clients should also switch to perceiving these people as valued members of society rather than objects of pity as is the case in traditional charity discourse.

In a traditional charity discourse, donor clients, although necessary to enable charities to gain funds to exist, often have less focus relative to service recipient clients. Charities should therefore increase focus on donor clients and recognise the need to have a balanced focus on both service recipient clients as well as donor clients. This increased focus on donor clients can be assisted via implementation of customer relationship management to identify key target donors, 
and utilisation of subsequent relationship marketing to develop bonds with key donors (individual and corporate) as well as government fund providers.

Management of charities need to recognise the existence of other charities, and determine the appropriate relationship to have with these charities. There will be a competitive focus relative to other charities due to competition for donations and government funds. However, there should also be co-operation for the common good in regards to collaboration on service provision to increase efficiency in an industry regularly battling for funds - this will result in the best use of funds to achieve maximum societal benefits.

Charities typically recognise the need to grow to create economies of scale needed to survive. Management should thus identify an appropriate target size for the charity, and implement a growth strategy to enable this size to be reached in a timely manner. This growth may be via merging with, or acquisition of other charities. Another option is to expand the range of services offered within the current geographic region, or expand into other regions - these options should however be considered in relation to the effect/consequences on other charities.

Associated with the client focus, charities need to identify important new key stakeholders and develop relationships with them. Charities need to not only determine a focus, but also then develop an appropriate interface with these stakeholders. For example, government funding bodies are a key potential source of revenue so it is essential to develop and maintain capability to interface with the key government personnel. Likewise, an appropriate interface is needed with the general public to gain new donors. The interface with service recipient clients should be via a holistic service delivery process including pro-active involvement of clients rather than the traditional reactive singular contacts. Charities should also be pro-active in increasing frequency of contact with donor clients. 


\section{Leadership}

The nature and history of traditional charities is such that the leadership (board of directors, top and middle management), although well intentioned, often do not have the skills and knowledge regarding how to operate a charity in the current environment, nor do they often recognise the need to change. As much as possible, leadership of a modern charity should be structured and operated similarly to a for-profit business - for reasons of efficiency and long-term viability. Whilst the Board of Directors of the charity will still be composed of unpaid volunteers, the number of Directors with business skills should be increased via pro-active targeting of appropriate people within the local business community. By developing a more professional Board of Directors, managerial interventions will be typical of a for-profit Board - with a focus on long-term strategy development with calculated business risk.

Similarly, top management (CEO) should ideally consist of experienced business professionals, preferably with not-for-profit experience, but possibly sourced from the for-profit sector, but who have an appropriate affiliation and understanding of the overall aims and underlying ethos of charities. With experience of management, their managerial interventions will be associated with change management, leveraging existing capabilities, improving service delivery, ensuring appropriate employee skills (via either retraining/upskilling existing employees if needed, or employing new people) and developing a formalised long-term strategy. Based on direction from the CEO, the middle management, consisting of existing high achieving employees and new business professionals should assist the CEO to transform the traditional charity discourse. 
Managers should also look to gain the services of external consultants for short-term access to specialist skills. For example, tax consultants can assist charities to capitalise on the taxation benefits afforded to not-for-profit organisations and restructure payment packages to employees to assist in making salaries more competitive with similar jobs in the for-profit sector.

To assist in the circulation of the new discourse, managers should focus on the employees and educate employees that the previous discourse was not best practice. Employment within charities can be very insular, with long-term employees having little, if any, exposure to other modes of operation. Employees tend to replicate past actions, and need to be informed of the need to change their mode of operation.

\section{Employees}

A vital requirement for success of the new discourse is employees who are committed to the new direction of the charity and who are willing to accept the higher level of personal accountability and new modes of day-to-day operation. Gaining legitimisation and acceptance from the existing employees and involving them in all stages of the discursive shift will minimise resistance. Managers need to recognise and appreciate how the discourse change impacts on both the organisational and individuals' identities and their work practices. Thus, during the change management process, management need to gain buy-in from the existing employees and ensure they possess the appropriate skills, and/or employ new professional staff with the relevant skills. This is required in both the service provision as well as the fundraising sections of the charity. Professionalism and the associated high accountability are essential.

\section{Organisational Structure}


The new discourse should contain a high level of formalisation to ensure quality services, with ongoing accountability via reference to KPI's. Whilst top management oversees the operations of the organisation, there should be de-centralisation of empowerment to the employees at any branches and regional centres to enable effective responses to local market needs. Formalised specialised departments with strong inter-department communications will ensure an efficient and effective organisational structure.

Optimum performance is achieved by high performing employees. The employees are likely to perform well if they perceive appropriate rewards. The underlying "raison d'etre" for charities is to provide services to people who are not always able to help themselves. By providing a high level of client service delivery and seeing their clients' benefit, employees will gain high intrinsic job satisfaction. Coupled with this, there is a need to also offer competitive financial rewards. The introduction of more professional job requirements will require an increase in salaries as the intrinsic reward of seeing service recipient clients helped will not by itself guarantee high performance from employees.

A new market oriented discourse is characterised by high levels of accountability, both individually and organisationally. The individual accountability should be based on personal KPI's, whilst organisational accountability is measured via KPI's and external audits.

A traditional charity is often associated with a low level of operational efficiency and less than optimum interdepartmental dynamics due to poor management skills as well as a reliance on volunteers working irregular hours. The modern discourse should utilise ongoing communications to develop a low conflict climate. This can be assisted by regular internal communication via newsletters, and establishment of cross-functional teams, as well as 
professional practice teams which bring together employees in similar job roles from different geographic locations.

\section{DISCUSSION AND CONTRIBUTIONS}

This paper addressed two research aims. First, we examined the process for effectively introducing market oriented discourses in a charity organisation. Based on examination of three cases and use of a Foucauldian (1991) approach we have identified how charities actively change the discourse boundaries, develop new positions and roles for employees, introduce new language and circulate the new discourse. This discourse transformation involved a phased approach involving new managerialism, then professionalism prior to embedding the MO. Second, based on these findings, we developed a conceptual praxis framework to guide charities to implement MO.

Whilst the four synthesis dimensions of MO are all relevant to charities, adoption is not an easy process and requires development of capabilities and changes to the mind-sets of a number of existing employees. The introduction of MO into the three charity case studies assisted in improved performance. This improved performance is exemplified by the increased revenue generation since the discourse transformations occurred. This reinforces the findings of Bennett (1998b) who determined that small/medium charities with high MO increased revenue moreso than charities with lower levels of MO. Improved service delivery and a more targeted range of services also exemplify the improved operating performance of the charities. However, the discourse transformations were not smooth, with various employees within the three charities either leaving during the course of the transformation, or taking time to accept the transformation. Following the introduction of MO into the charities, the resultant discourse in 
each charity was characterised by a more businesslike and professional approach with numerous standard practices and procedures to formalise and embed the new discourse.

The research has indicated that charities can successfully introduce a more market oriented discourse for the benefit of all stakeholders, but caution needs to be taken to ensure it is introduced in an appropriate manner and new managerialism and professionalism need to be introduced before market orientation can be embedded. A key finding of the research is that an extremely strong client-first ethos exists amongst existing employees in the charity sector, particularly amongst service providers. Although a discourse transformation reflecting a more market oriented approach supplants the previous legacy charity discourse, a significant remnant for employees was the emphasis on customers, a foundation for the transformation. The emphasis of customers was maintained, albeit via new and more professional service delivery processes. Continuing a 'client-first' ethos may potentially cause ongoing challenges as management wrestle with limited resources, maintaining ongoing efficiency and ensuring sustainability but a 'client-first' ethos is the raison d'etre for these organisations. However, the conceptual praxis framework provided in Table 1 recommends appropriate actions to successfully transform a traditional charity into a modern, market oriented organisation.

Research regarding the actual implementation of MO is sparse (Beverland and Lindgreen, 2007) both within the for-profit as well as the not-for-profit sectors. Also, relative to the forprofit sector, research regarding MO in general within not-for-profit organisations including charities is an under-researched area (Bennett, 2005; Sargeant et al., 2002; Warnaby \& Finney, 2005). This research thus not only expands our general knowledge regarding how an organisation can successfully introduce MO, but it also specifically advances our knowledge within the not-for-profit sector. We consider the research questions addressed in this paper to be 
of interest and of importance to both academics and practitioners as they specifically examine the manner in which charities actually operate and utilise marketing theory. This research pioneers the actual examination of the process of implementing MO into charities and as such responds to the comment by Tadajewski and Hewer (2011) 'that there needs to be a concerted effort in understanding how practitioners engage in marketing activities' (p. 451). This paper explicitly addresses the lack of practitioner perspectives (Cornelissen \& Lock, 2005). Based on actual examination of how managers within three charities introduced and engaged in market orientation, our development of a resultant praxis framework is thus a significant contribution to the literature and is aimed to assist charity managers to improve performance. This improved performance will potentially have a major impact in assisting society at large.

In response to the 'so what' (Tynan, 2006, p. 573) question often asked regarding the contributions of research, we contend that the not-for-profit sector plays a key role in society, that MO is relevant for the not-for-profit sector, that there has been minimal previous examination of how successful implementation of MO can be achieved within the sector, and thus the development of a framework to introduce MO into the charity sub-sector of the not-forprofit sector offers a significant contribution. It addresses a gap by providing knowledge regarding how practitioners can successfully introduce MO into charities. Thus, we consider the research will ‘transform the intellectual and practical landscape’ (Tadajewski \& Hewer, 2011, p. 452).

Using Bourner's (1996) checklist, the research fills gaps in the current literature; assists in clarifying the specific areas in which existing MO ideas apply; offers synthesis of existing ideas and looks at existing situations from a novel theoretical perspective (discourse theory). The research presents an examination of the process of change within an organisation as management 
introduces some form of MO. We now know that, given the historical traditional nature of charities, introduction of MO into a charity (based on the analysis of three case organisations) firstly requires a transition through new managerialism and professionalism phases. This provides an interesting comparison with the research conducted by Gebhardt, Carpenter and Sherry Jr (2006) who suggested a four-stage model for the process of introducing MO in forprofit organisations namely, initiation, reconstitution, institutionalisation and maintenance. It also provides a useful addition to the research conducted by Beverland and Lindgreen (2007) who examined introduction of market orientation in two agricultural organisations using Lewin's (1951) broad three-stage change process model, namely unfreezing, movement, refreezing.

Given the claims that marketing, and hence MO is relevant not just in the for-profit arena but is also relevant in the not-for-profit arena (e.g. Kotler \& Levy, 1969), the research has reaffirmed and clarified that MO, in some form, is appropriate for at least the charity sub-sector of the not-for-profit arena but needs to be introduced in a very specific manner to address the strong historical charity ethos within the organisations. The inherent nature of traditional charities is such that the specific drivers and consequences of introducing market orientation into charities is different than in the for-profit sector and thus is different than simple replication.

The research is highly original as it sets down 'a major piece of new information in writing for the first time' (Phillips \& Pugh, 2000, p. 63) based on first hand data collected from charity employees. Likewise, the research contains elements of 'novelty and continuity' (Tadajewski \& Hewer, 2011, p. 450) by continuing the examination of the MO concept but from a novel perspective - a discourse transformation perspective. The Foucauldian (1991) framework was found to be useful in providing a worthwhile and convenient guide to detecting the changes that affect discursive formations. The research has demonstrated that complex discourse theory 
can be utilised in an applied manner to analyse an organisation to offer insights into marketing praxis related to organisational change. Change is vitally connected to what things mean to people, how they communicate, and what actions they take. The discourse approach provided useful theoretical insights to assist in framing an examination of organisational change and established discourse as relevant to marketing.

The current research also offers ideas for future research. The current research was based on multiple case studies of domestic charities based in south-eastern Australia. Charities operate in numerous countries around the world and they may operate under differing and specific environmental factors and dynamics. In terms of future research, additional cases covering a wider range of charities both within Australia as well as in other countries could assist in finetuning the developed praxis framework.

\section{CONCLUSION}

We have examined the manner in which three Australian charities have successfully introduced a market orientation. The research has shown that poorly operating charities can gain improved organisational performance via the introduction of MO. The inherent differences between the for-profit and the charity sector, particularly the motivations and beliefs of employees, do however present unique managerial challenges and therefore require a specific manner of introduction of market orientation within the charity sector. The praxis framework subsequently developed and provided in Table 1 can guide charity managers towards successful introduction of market orientation. We strongly suggest that managers keep in mind the key aspects of discourse transformation - displacement of discourse boundaries, the position and role of the speaking subject, language and circulation of the new discourse (Foucault, 1991). By being 
aware of these issues, managers can be better placed to utilise appropriate processes to maximise the smooth introduction of their proposed new market oriented discourse. Our world is everchanging, and considering the key role of charities in assisting society, we hope this research has increased our knowledge of how charities can become more market oriented to their improve performance for the benefit of their clients. 


\section{REFERENCES}

Aaker, D., Kumar, V., Day, G., \& Lawley, M. (2005). Marketing research - The Pacific rim edition. Sydney: Wiley.

Arana. (2008). Annual report 2007-2008.

Bennett, R. (1998a). Charities, organisational learning and market orientation: A suggested measure of the propensity to behave as a learning organisation. Journal of Marketing Practice: Applied Marketing Science, 4(1), 5-25.

Bennett, R. (1998b). Market orientation among small to medium sized UK charitable organisations: Implications for fund-raising performance. Journal of Nonprofit \& Public Sector Marketing, 6(1), 31-45.

Bennett, R. (2005). Competitive environment, market orientation, and the use of relational approaches to the marketing of charity beneficiary services. Journal of Services Marketing, 19, 453-469.

Beverland, M., \& Lindgreen, A. (2007). Implementing market orientation in industrial firms: A multiple case study. Industrial Marketing Management, 36, 430-442.

Bourner, T. (1996). The research process: Four steps to success. In T. Greenfield (Ed), Research Methods - Guidance for Postgraduates (pp. 7-11). London, Arnold.

Bukari. (2006). Annual report 2005/6.

Bukari. (2007). Annual report 2006/7.

Bukari. (2008). Annual report 2007/8.

Bukari. (2009). Annual report 2008/9.

Bukari. (n.d.-a). Our history. Retrieved from http://www.bukari.org.au/our_history.asp

Bukari. (n.d.-b). About us. Retrieved from http://www.bukari.org.au/about_us.asp 
Bukari. (n.d.-c). Our purpose. Retrieved from http://www.bukari.org.au/our_purpose.asp

Camira. (2007). Strategic plan 2007-2009.

Charity Commission. (2011). The Charity Commission's role and regulatory approach. Retrieved from http://http://www.charity-commission.gov.uk/about_us/contacting_us/ role_and_regulatory_approach.aspx

Cornelissen, J., \& Lock, A. (2005). The uses of marketing theory: Constructs, research propositions, and meaningful implications. Marketing Theory, 5, 165-184.

Covaleski, M., Dirsmith, M., Heian, J., \& Sajay, S. (1998). The calculated and avowed: Techniques of discipline and struggles over identity in the big six public accounting firms. Administrative Science Quarterly, 43, 293-327.

Creswell, J. (2003). Research design; qualitative, quantitative, and mixed methods approaches (2nd ed.), Thousand Oaks, CA: Sage.

Daystar Council. (2011). Is it viable to set up a non profit organization ? Retrieved from http://http://www.startnonprofitorganization.com/u-s-statewise-nonprofit-incorporationprocess

Deshpande, R., Farley, J., \& Webster Jr, F. (1993). Corporate culture, customer orientation and innovativeness in Japanese firms: A quadrad analysis. Journal of Marketing, 57(1), 2337.

Drucker, P. (1990). Managing the Non-profit Organization. Oxford: Butterworth Heinemann.

Drucker, P. (1954). The Practice of Management. New York, NY: Perennial Library.

Duque-Zuluaga, L., \& Schneider, U. (2008). Market orientation and organisational performance in the nonprofit context: Exploring both concepts and the relationship between them. Journal of Nonprofit \& Public Sector Marketing, 19(2), 25-47. 
Eisenhardt, K. (1989). Building theories from case study research. The Academy of Management Review, 14, 532-550.

Ellis, N., Jack, G., \& Higgins, M. (2005). (De)constructing the market for animal feeds: A discursive study. Journal of Marketing Management, 21, 117-146.

Ellis, N., Fitchett, J., Higgins, M., Jack, G., Lim, M., Saren, M., \& Tadajewski, M. (2011). Marketing: A Critical Textbook. London: Sage.

Evetts, J. (2003). The construction of professionalism in new and existing occupational contexts; Promoting and facilitating occupational change. International Journal of Sociology and Social Policy, 23(4), 22-35.

Feagin, J., Orum, A., \& Sjoberg, G. (1991). A case for case study. Chapel Hill: University of North Carolina.

Foucault, M. (1991). Politics and the study of discourse. In: G. Burchell, C. Gordon, P. Miller (Eds.), The Foucault Effect - Studies in Governmentality, with two lectures by and an interview with Michael Foucault (pp. 53-72). Chicago, University of Chicago.

Fournier, V. (1999). The appeal to 'Professionalism' as a disciplinary mechanism. Social Review, 47, 280-307.

Fulcher, G. (1989). Disabling Policies ? A Comparative Approach to Education Policy and Disability. London: Falmer Press.

Gainer, B., \& Padanyi, P. (2005). The relationship between market-oriented activities and market-oriented culture: Implications for the development of market orientation in nonprofit service organisations. Journal of Business Research, 58, 854-862. 
Gebhardt, G., Carpenter, G., \& Sherry Jr, J. (2006). Creating a market orientation: A longitudinal, multifirm, grounded analysis of cultural transformation. Journal of Marketing, 70(4), 37-55.

Gewirtz, S., \& Ball, S. (2000). From 'Welfarism' to 'New Managerialism': shifting discourses of school headship in the education marketplace. Discourse, 21, 253-268.

Gillham, B. (2000). Case Study Research Methods. London: Continuum.

Glaser, B., \& Strauss, A. (1967). The Discovery of Grounded Theory: Strategies for Qualitative Research. Chicago, IL: Aldine.

Gonzalez, L., Vijande, M., \& Casielles, R. (2002). The market orientation concept in the private nonprofit organisational domain. International Journal of Nonprofit and Voluntary Sector Marketing. 7, 55-67.

Gummesson, E. (2007). The principles of knowledge creation methods. In B. Gustavsson (Ed.), Case Study Research. Cheltenham: Edward Elgar.

Haigh, M. (n.d.). The many faces of case study research. Retrieved from http://www.ace.ac.nz/learning/science/articles/a5.asp

Harris, L. (1998). Barriers to market orientation: The view from the shopfloor. Marketing Intelligence \& Planning, 16, 221-228.

Harris, L. (2000). The organisational barriers to developing market orientation. European Journal of Marketing, 34, 598-624.

Harris, L., \& Ogbonna, E. (2001). Leadership style and market orientation: An empirical study. European Journal of Marketing, 35, 744-764.

Harris, L., \& Piercy, N. (1999). Management behaviour and barriers to market orientation in retailing companies. The Journal of Services Marketing, 13, 113-131. 
Jaworski, B., \& Kohli, A. (1993). Market orientation: Antecedents and consequences. Journal of Marketing, 57(3), 53-70.

Kennedy, K., Goolsby, J., \& Arnould, E. (2003). Implementing a customer orientation: Extension of theory and application. Journal of Marketing, 67(4), 67-81.

Kohli, A., \& Jaworski, B. (1990). Market orientation: The construct, research propositions, and managerial constructs. Journal of Marketing, 54(2), 1-18.

Kohli, A., Jaworski, B., \& Kumar, A. (1993). MARKOR: A measure of market orientation. Journal of Marketing Research, 30, 467-477.

Kotler, P., \& Andreasen, A. (1996). Strategic Marketing for Nonprofit Organizations (5th ed.). Upper Saddle River, NJ: Prentice-Hall.

Kotler, P., \& Armstrong, G. (2012). Principles of Marketing (14th ed.). Boston, MA: Pearson.

Kotler, P., \& Levy, S. (1969). Broadening the concept of marketing. Journal of Marketing, 33(1), 10-15.

Lafferty, B., \& Hult, G. (2001). A synthesis of contemporary market orientation perspectives. European Journal of Marketing, 35, 92-109.

LeCompte, MD., \& Preissle, J. (1993). Ethnography and Qualitative Design in Educational Research. San Diego, CA: Academic Press.

Levitt, T. (1960). Marketing Myopia. Harvard Business Review, 38(4), 45-56.

Lewin, K. (1951). Field theory in social science. New York, NY: Harper \& Row.

Liao, M-N., Foreman, S., \& Sargeant, A. (2001). Market versus societal orientation in the nonprofit context. International Journal of Nonprofit and Voluntary Sector Marketing, 6, 254-268.

Lincoln, Y., \& Guba, E. (1985). Naturalistic Enquiry. Beverley Hills, CA: Sage. 
Mason, K., \& Harris, L. (2005). Pitfalls in evaluating market orientation; An exploration of executives' interpretations. Long Range Planning, 38, 373-391.

McDonald, R. (2007). An investigation of innovation in nonprofit organisations: The role of organisational mission. Nonprofit and Voluntary Sector Quarterly, 36, 256-281.

Meyer, H-D. (2002,). The new managerialism in education management: Corporatization or organizational learning. Journal of Educational Administration, 40, 534-551.

Miles, M., \& Huberman, A. (1994). An Expanded Sourcebook: Qualitative Data Analysis (2nd ed.). Thousand Oaks, CA: Sage.

Modi, P., \& Mishra, D. (2010). Conceptualising market orientation in non-profit organisations: Definition, performance, and preliminary construction of a scale. Journal of Marketing Management, 5, 548-569.

Motion, J., \& Leitch, S. (1996). A discursive perspective from New Zealand: Another world view. Public Relations Review, 22, 297-309.

Mukkerji, G 2004, Introduction to Social Marketing. New Delhi: India Research Press.

Narver, J., \& Slater, S. (1990). The effect of a market orientation on business profitability. Journal of Marketing, 54(4), 20-35.

Parkhe, A. (1993). "Messy" research, methodological predispositions and theory development in international joint ventures. The Academy of Management Review, 18, 227-268.

Patton, M. (2002). Qualitative Research \& Evaluation Methods (3rd ed.). Thousand Oaks, CA: Sage.

Phillips, E., \& Pugh, D. (2000). How to Get a PhD - A Handbook for Students and Their Supervisors. Philadelphia, PA: Open University Press. 
Pope, J., Isely, E., \& Asamoa-Tutu, F. (2009). Developing a marketing strategy for nonprofit organizations: An exploratory study. Journal of Nonprofit \& Public Sector Marketing, 21, 184-201.

Productivity Commission. (2010). Contribution of the Not-for-profit Sector. Productivity Commission, Research Report, Jan 2010.

Ruekert, R. (1992). Developing a market orientation: An organisational strategy perspective. International Journal of Research in Marketing, 9, 225-245.

Sargeant, A., Foreman, S., \& Liao, M-N. (2002). Operationalizing the marketing concept in the nonprofit sector. Journal of Nonprofit \& Public Sector Marketing, 10(2), 41-65.

Shapiro, B. (1988). What the hell is 'market oriented'? Harvard Business Review, 66(6), 119-125.

Shoham, A., Rose, G., \& Kropp, F. (2005). Market orientation and performance: A meta analysis. Marketing Intelligence and Planning, 23, 435-454.

Sinclair, A. (1996). Leadership in administration: Rediscovering a lost discourse. In P. Weller \& G. Davies (Eds.), New Ideas, Better Government. St Leonards: Allen \& Unwin.

Stake, R. (1995). The Art of Case Study Research. Thousand Oaks, CA: Sage.

Steinman, C., Deshpande, R., \& Farley, J. (2000). Beyond market orientation: When customers and suppliers disagree. Journal of the Academy of Marketing Science, 28, 109-119.

Strauss, A., \& Corbin, J. (1998). Basics of Qualitative Research: Techniques and Procedures for Developing Grounded Theory (2nd ed.). Thousand Oaks, CA: Sage.

Tadajewski, M., \& Hewer, P. (2011). Intellectual contributions and 'gap-spotting'. Journal of Marketing Management, 27, 449-457.

Taghian, M. (2010). Marketing planning: Operationalising the market orientation strategy. Journal of Marketing Management, 26, 825-841. 
Tynan, C. (2006). Editorial: Academy of marketing new blood special issue. Journal of Marketing Management, 22, 573-577.

van Raaij, E., \& Stoelhorst, J. (2008). The implementation of a market orientation: A review and integration of the contributions to date. European Journal of Marketing, 4, 1265-1293.

Vickers, M., \& Kouzmin, A. (2001). New managerialism and Australian police organizations. The International Journal of Public Sector Management, 14, 7-26.

Warnaby, G., \& Finney, J. (2005). Creating customer value in the not-for-profit sector: A case study of the British library. International Journal of Nonprofit and Voluntary Sector Marketing, 10, 183-195.

Webb, D., Webster, C., \& Krepapa, A. (2000). An exploration of the meaning and outcomes of a customer-defined market orientation. Journal of Business Research, 48, 101-112.

Wong, V., Saunders, J., \& Doyle, P. (1989). The barriers to achieving stronger market orientation in British companies: An exploratory study. 22nd Annual Conference Proceedings, Marketing Education Group, Glasgow Business School, pp. 35-64.

Wood, L., \& Kroger, R. (2000). Doing Discourse Analysis: Methods For Studying Action in Talk and Text. Thousand Oaks, CA: Sage.

Yin, R. (1984). Case Study Research. Beverley Hills, CA: Sage.

Yin, R. (1993). Applications of Case Study Research. Newbury Park: Sage.

Yin, R. (1994). Case Study Research - Design and Methods (2nd ed.). Thousand Oaks, CA: Sage. 
Table 1. Praxis Framework For Development of a Market Oriented Charity.

\begin{tabular}{|c|c|}
\hline & Market Oriented Charity \\
\hline \multicolumn{2}{|l|}{ CHARACTERISTICS } \\
\hline \multicolumn{2}{|c|}{ Organisation Mission (values and beliefs) and Strategy } \\
\hline \multicolumn{2}{|l|}{ Client focus } \\
\hline $\begin{array}{l}\text { o Service recipient } \\
\text { clients }\end{array}$ & $\begin{array}{l}\text { Maintain and reinforce emphasis of high service recipient client focus } \\
\text { characteristic of traditional charity. }\end{array}$ \\
\hline & $\begin{array}{l}\text { Switch from portrayal of service recipient client as subject of pity to portrayal of } \\
\text { service recipient client as valued member of society. }\end{array}$ \\
\hline o Donor clients & $\begin{array}{l}\text { Utilise customer relationship management to identify key target donors. } \\
\text { Implement relationship marketing to develop bonds with key donors (individual } \\
\text { and corporate) and government fund providers. }\end{array}$ \\
\hline Competitive focus & $\begin{array}{l}\text { Increase collaboration with other charities for synergistic service delivery to } \\
\text { minimise resource wastage and to provide service recipient client with most } \\
\text { appropriate service provision. Not withstanding, recognise high competition with } \\
\text { other charities for individual and corporate donations and government funds. }\end{array}$ \\
\hline Organisational size & $\begin{array}{l}\text { Grow to achieve economies of scale to improve performance. Grow via increase } \\
\text { in market share within existing markets and/or expansion of geographic regions } \\
\text { served and/or via increased range of services offered. } \\
\text { Reduce growth once no further economies of scale can been achieved. }\end{array}$ \\
\hline Stakeholder relationships & $\begin{array}{l}\text { Identify key stakeholders. } \\
\text { Develop strategic and well-planned relationships with key stakeholders. }\end{array}$ \\
\hline \multicolumn{2}{|l|}{$\begin{array}{l}\text { Interface with external } \\
\text { stakeholders }\end{array}$} \\
\hline o Funding bodies & $\begin{array}{l}\text { Develop and maintain capability to increase success in gaining access to } \\
\text { government funds. }\end{array}$ \\
\hline o Publics & Increase interface to gain new donor clients. \\
\hline $\begin{array}{l}\text { o Service recipient } \\
\text { clients }\end{array}$ & $\begin{array}{l}\text { Introduce holistic/customised service approach with pro-active involvement of } \\
\text { service recipient client in service provision. }\end{array}$ \\
\hline o Donor clients & Increase pro-active frequency of contact. \\
\hline
\end{tabular}

continued overleaf 
Table 1(Continued). Praxis Framework For Development of a Market Oriented Charity.

\begin{tabular}{|c|c|}
\hline & Market Oriented Charity \\
\hline \multicolumn{2}{|l|}{ Leadership } \\
\hline Board of Directors & $\begin{array}{l}\text { Increase proportion of business professionals via pro-active targeted invitations } \\
\text { to potential candidates. }\end{array}$ \\
\hline $\begin{array}{l}\text { o Managerial } \\
\text { interventions }\end{array}$ & $\begin{array}{l}\text { Ongoing professional monitoring of operations. Interventions as appropriate to } \\
\text { ensure continuance of smooth operations. }\end{array}$ \\
\hline o Emphasis & Ensure long-term strategy development. \\
\hline o Risk aversion & Introduce calculated risk to enable achievement of organisation goals. \\
\hline Top Management (CEO) & Employ experienced business professional generally from for-profit sector. \\
\hline $\begin{array}{l}\text { o Managerial } \\
\text { interventions }\end{array}$ & $\begin{array}{l}\text { Utilise high involvement during establishment phase in leading change - } \\
\text { - } \quad \text { change management skills } \\
\text { - } \quad \text { levills/capability audit } \\
\text { - } \quad \text { develop formalised strategy } \\
\text { - } \quad \text { gain buy-in from all organisation } \\
\text { - } \quad \text { introduce new language } \\
\text { - } \quad \text { increase staff training } \\
\text { - } \quad \text { increase internal marketing } \\
\text { - } \quad \text { new managerial job titles } \\
\text { Reduce involvement following embedding change in discourse. } \\
\text { Subsequent ongoing overview of operations. }\end{array}$ \\
\hline o Emphasis & $\begin{array}{l}\text { Ensure organisational efficiency and long-term strategic perspective. } \\
\text { Introduce diverse range of highly specific and appropriate services. } \\
\text { Diversify revenue sources including increased government funding and } \\
\text { increased social entrepreneurship including establishment of for-profit activities. } \\
\text { Ensure ongoing staff training as appropriate to ensure appropriate employee skill } \\
\text { levels. }\end{array}$ \\
\hline o Risk aversion & $\begin{array}{l}\text { Utilise calculated level of risk. } \\
\text { Increase level of entrepreneurialism to assist achievement of organisation goals. }\end{array}$ \\
\hline Middle Management & $\begin{array}{l}\text { Utilise high achieving, experienced internal service employees and new business } \\
\text { professionals typically from for-profit sector. }\end{array}$ \\
\hline $\begin{array}{l}\text { o Managerial } \\
\text { interventions }\end{array}$ & $\begin{array}{l}\text { Enable opportunity for significant ongoing consultation and input into } \\
\text { organisational strategic goals and tactics. }\end{array}$ \\
\hline o Emphasis & $\begin{array}{l}\text { Continue organisational efficiency. } \\
\text { Increase involvement in medium and long-term strategy. } \\
\text { Increase use of promotion- personal selling, advertising, publicity, public } \\
\text { relations. }\end{array}$ \\
\hline o Risk aversion & Increase opportunity for risk-taking to achieve organisational objectives. \\
\hline
\end{tabular}


Table 1(Continued). Praxis Framework For Development of a Market Oriented Charity.

\begin{tabular}{|c|c|}
\hline & Market Oriented Charity \\
\hline Employees & \\
\hline $\begin{array}{l}\text { Service providers } \\
\text { o Organisational } \\
\text { commitment } \\
\text { o Identity } \\
\text { o Esprit de corps } \\
\text { o Perception of marketing }\end{array}$ & $\begin{array}{l}\text { Employ staff with high commitment to new discourse. } \\
\text { Employ professionals willing to accept high accountability. } \\
\text { Employee staff that embrace the new discourse. } \\
\text { Educate staff regarding the value of selected use of “7P's” to achieve } \\
\text { organisational goals. }\end{array}$ \\
\hline $\begin{array}{l}\text { Fundraisers } \\
\text { o Organisational } \\
\text { commitment } \\
\text { o Identity } \\
\text { o Esprit de corps } \\
\text { o Perception of marketing }\end{array}$ & $\begin{array}{l}\text { Employ staff with high commitment to new discourse. } \\
\text { Employ professionals willing to accept high accountability. } \\
\text { Employ staff that embrace the new discourse. } \\
\text { Educate staff regarding use of 7P's to achieve organisational revenue generation } \\
\text { goals. }\end{array}$ \\
\hline Organisational Structure & \\
\hline $\begin{array}{l}\text { Organisational Systems } \\
\text { o Formalisation } \\
\text { o Centralization } \\
\text { o Departmentalisation } \\
\text { o Rewards } \\
\text { - Intrinsic / "raison } \\
\quad \text { d'etre" } \\
\text { - Financial } \\
\text { - Respect }\end{array}$ & $\begin{array}{l}\text { Develop high level of formalisation to ensure service quality and ease of } \\
\text { reporting for government audits. } \\
\text { Introduce high use of KPI’s. } \\
\text { De-centralise to cater to localised service recipient client needs and wants but } \\
\text { overseen by centralised top management to ensure co-ordinated organisation. } \\
\text { Create formalised specialist departments and enable strong inter-department } \\
\text { communications. } \\
\text { Reinforce employee satisfaction from high quality service recipient client service } \\
\text { delivery. } \\
\text { Offer competitive salaries to attract appropriate staff. } \\
\text { Provide high respect due to predominantly professional employees. }\end{array}$ \\
\hline $\begin{array}{l}\text { o Accountability } \\
\text { - Personal } \\
\text { - Organisational }\end{array}$ & $\begin{array}{l}\text { Emphasise employees' need for high personal accountability based on personal } \\
\text { KPI's. } \\
\text { Ensure ongoing processes enable compliance with audits by government fund } \\
\text { providers. } \\
\text { Minimise administrative expenses to appease various stakeholders including } \\
\text { general public and donor clients. }\end{array}$ \\
\hline $\begin{array}{l}\text { Interdepartmental } \\
\text { Dynamics } \\
\text { o Conflict } \\
\text { o Connectedness }\end{array}$ & $\begin{array}{l}\text { Develop low conflict climate. } \\
\text { - Utilise ongoing communications and publicise role of each department to } \\
\text { enable high level of connectedness. } \\
\text { - Use regular integrated internal communications. } \\
\text { - Establish leadership forums / cross-functional teams / professional practice } \\
\text { teams. }\end{array}$ \\
\hline
\end{tabular}




\section{Appendix 1. Perceived level of market orientation.}

Component of Market Orientation (Lafferty \& Hult 2001)

Emphasis

on

customer
Importance
of

information
Interfunctional

coordination
Taking

action

\section{Arana}

Pre

Discourse

Transformation

Discourse Transformation

\begin{abstract}
High
e.g. 'focus ... on needs of clients'
\end{abstract}

High

e.g. 'very client focussed'

Low
e.g. 'Probably not
well'

Medium

e.g. 'will take a more structured approach,

\author{
Medium \\ e.g. some \\ management \\ communication
}

High

e.g. 'there is more communication'

\author{
Medium \\ e.g. progress \\ towards formation \\ of committees
}

High

e.g. formation of committees

\section{Bukari}

Pre

Discourse

Transformation

Post

Discourse

Transformation
Medium

e.g. 'opened offices ... without any real service plan'

High

e.g. 'that is why we are here'
Low e.g. 'wasn't geared up to even capture data'

Medium e.g. 'that is something that wasn't here before'
Low

e.g. 'it has the typical silos'

High

e.g. 'there is a lot of communication now. There wasn't before'
Medium e.g. no standard practices and procedures

\section{High}

e.g. 'we've got service models designed and developed now'

\section{Camira}

Pre

Discourse

Transformation

Post

Discourse Transformation
High

e.g. 'we are here for the clients'

High

e.g. 'what we're here for'
Low

e.g. 'we are not very good at that'

Medium

e.g. 'we are trying to get better'
Low e.g. 'silo mentality'

Medium

e.g. increased investment in training
Medium e.g. 'it is improving'

High e.g. 'more businesslike processes'

\section{N.B. In relation to 'emphasis on customer' most comments from respondents related to service} recipient clients. 